\title{
Similarities between L'Enfant's Urban Plan for Washington, DC, and the Royal Site of Aranjuez, Spain
}

\author{
C. San-Antonio-Gómez ${ }^{1}$; C. Velilla ${ }^{2}$; and F. Manzano-Agugliaro ${ }^{3}$
}

\begin{abstract}
The influence of Versailles on L'Enfant's 1791 plan for the city of Washington, DC, is well known. Less well known are the surprising similarities between Washington and the forma urbis of the Royal Site of Aranjuez in Spain. For example, the cities share the same diagram of two large, rectangular spaces arranged in an L shape, at the extremes of which are located, analogously, the most emblematic buildings: The Capitol and the White House in one instance, and the Royal Palace and the Church of San Antonio in the other. There are also connections between some of the diagonal avenues; between the Plaza de las Doce Calles in Aranjuez and the 12 avenues radiating from the Capitol; and between the trident of Parterre Garden in Aranjuez and the trident formed in L'Enfant's plan by Pennsylvania Avenue NW, Maryland Avenue SW, and Avenue H. Based on these facts, this paper investigates parallels that have hitherto been ignored. It is not possible to conclude, based on the currently available information, that L'Enfant was familiar with the plan for Aranjuez, which was sent in 1775 to the main European courts, where it is conserved in their libraries. A copy of the plan is also the Library of Congress in Washington, DC. There is evidence that L'Enfant's father, and possibly he himself, saw it in Paris at the Académie Royale de Peinture et de Sculpture, at which L'Enfant was studying before his departure for the United States. He may also have seen it during a visit to Paris in 1783, when the creation of a new capital had been proposed and he was a candidate to plan it because of his relationship with George Washington. Similarly, Thomas Jefferson may have seen the plan during his time as ambassador in Paris, given that, in his own sketch for the new capital, he situated the White House and the Capitol in the same compositional relationship as L'Enfant did later. These similarities may also simply be coincidence; in any case, they invite questions. DOI: 10.1061/(ASCE)UP.1943-5444.0000495. ( 2019 American Society of Civil Engineers.
\end{abstract}

Author keywords: Washington; Urban planning; Aranjuez; Domingo de Aguirre; L'Enfant.

\section{Introduction}

Studies related to urbanism or the process of urbanization are the major inputs to historical research on cities (Chen et al. 2017). The history of urban planning is both the history of ideas about the city and the regulatory practice of its construction and transformation (Pipa et al. 2017), in which theoretical approaches and instruments of action differ ( $\mathrm{Li}$ et al. 2017). The modern city reflects the grandeur of the state and the absolutist monarchies of the sixteenth and seventeenth centuries, so all expenses at that time to beautify it were justified. At that time, public and administrative buildings were of great importance and began to be points of reference for citizens. The main streets of cities were widened; groves, walks, and great squares appeared; and attempts were made to order urban growth according to predefined regular figures. The exemplary model city is Versailles.

The literature on the origins of L'Enfant's plan for Washington, DC is very abundant. All the researchers agree on the similarities of L'Enfant's design with Versailles. As an example of this extensive

\footnotetext{
${ }^{1}$ Professor, Dept. of Cartographic Engineering, Geodesy and Photogrammetry, Polytechnic Univ. of Madrid, Madrid 28040, Spain.

${ }^{2}$ Senior Lecturer, Dept. of Cartographic Engineering, Geodesy and Photogrammetry, Polytechnic Univ. of Madrid, Madrid 28040, Spain.

${ }^{3}$ Professor, Dept. of Engineering, Univ. of Almería, Almería 04120, Spain (corresponding author). ORCID: https://orcid.org/0000-0002-0085 -030X. Email: fmanzano@ual.es

Note. This manuscript was submitted on April 14, 2017; approved on August 2, 2018; published online on January 23, 2019. Discussion period open until June 23, 2019; separate discussions must be submitted for individual papers. This paper is part of the Journal of Urban Planning and Development, (C) ASCE, ISSN 0733-9488.
}

literature, Helfrich (2016) affirmed that "It is generally conceded that the plan for the national capital was conceived in the formal manner of Le Nôtre, ... in some details the plan of Versailles may have influenced the design." Reps (1992) did not limit the similarities to the gardens of Versailles, but also considered the Tuileries and the present avenue of the Champs-Élysées, which was then a track through the woods that ended at the roundabout which is now the current Place de l'Etoile; in this regard, Berg (2008) found the same similarities. However, in spite of this evidence, it does not appear in any document that L'Enfant claimed to have been inspired himself by Versailles (National Register of Historic Places 2016).

Similarly, no document nor any of the literature claims similarities between Washington, DC and the Real Sitio de Aranjuez (the Royal Site of Aranjuez) in Spain. However, these similarities cannot be overlooked. In a general view of L'Enfant's plan, we focus on the genesis of the design of the new capital, which merges an orthogonal grid with diagonal avenues, following European baroque models. The L composition of the White House and Capitol around the river deserves special comparison with Aranjuez (Fig. 1). Therefore, this manuscript investigates the similarities, hitherto unknown, between the L'Enfant plan for Washington, DC and the Real Sitio de Aranjuez. As a first hypothesis, we ask whether L'Enfant, in Paris, could have been familiar with the map of the Real Sitio de Aranjuez by Domingo de Aguirre, who, like L'Enfant, was a military engineer. As a second hypothesis, the question arises whether Jefferson, as ambassador in Paris (17841789), could have had access to the Aranjuez plans. Finally, if these hypotheses are possible, the similarities between both urban designs must be determined to conclude whether it is possible to establish their analogy. 


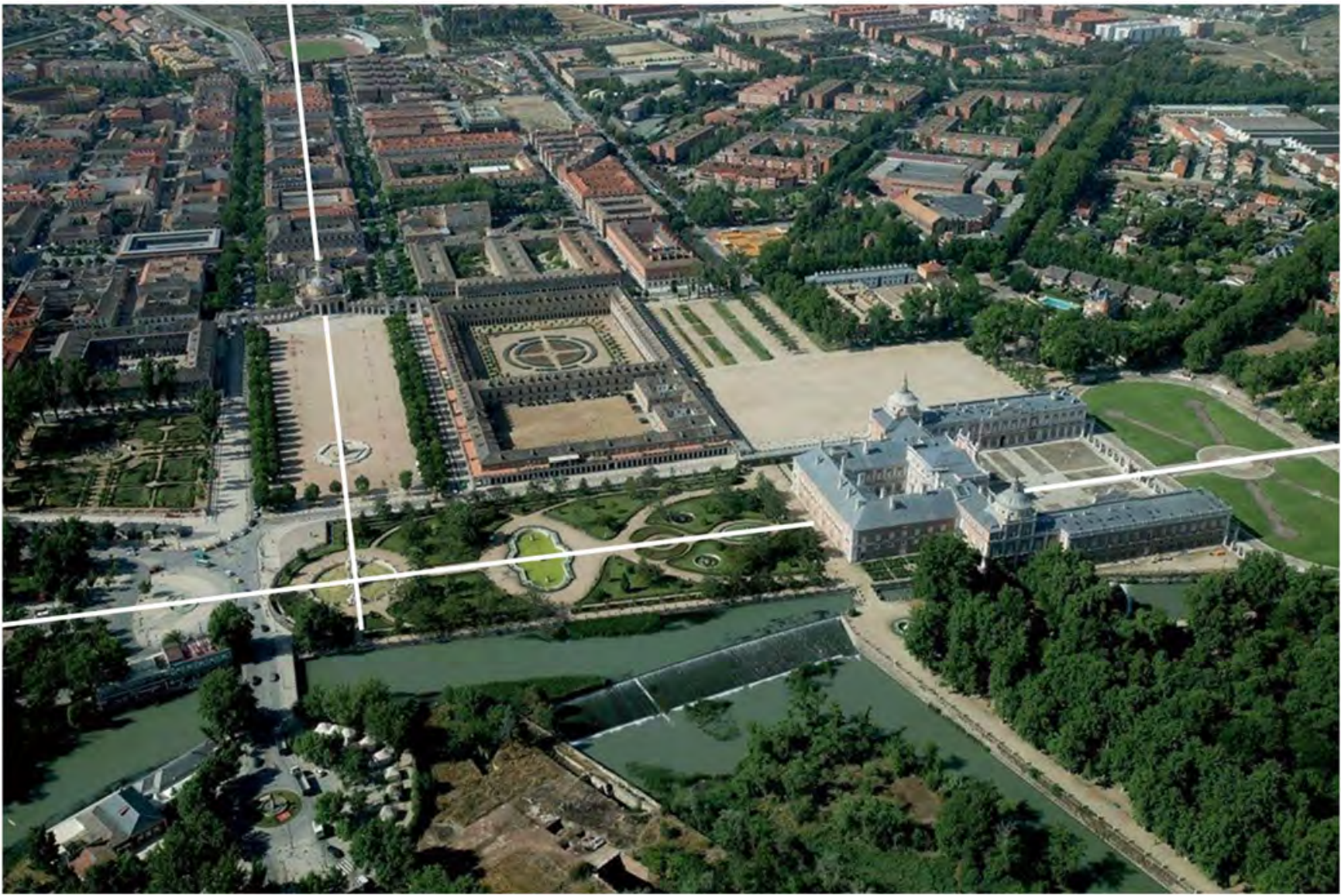

Fig. 1. Aerial view of compounds of Royal Palace and Plaza de San Antonio de Aranjuez, with their two perpendicular axes added by authors. (Base image reprinted from Aranjuez 2017.)

\section{Historical Chronology of L'Enfant's Plan for Washington, DC versus Plan for Royal Site of Aranjuez}

The first question was whether L'Enfant could have been familiar with the map of Domingo de Aguirre. Through historical chronology, the moments and circumstances that could determine whether he could have known of that plan are analyzed. This raises two questions: where was the plan of Aranjuez, and where was L'Enfant at that time?

It must be determined whether L'Enfant, who enlisted in the Continental Army in 1777 (Berg 2008), could have seen the plans for the Royal Site of Aranjuez by the military engineer Domingo de Aguirre while he was in Paris. King Charles III of Spain ordered that two copies of the plan be sent to all of the European courts immediately after it was recorded. San-Antonio-Gómez (2015) cites the reference from the Palace Archive, Ca/14.268. In 1775, 267 copies of the 16-page plan and the views of the Royal Site were printed (Sancho 1991, p. 37). Hence, the plans would have arrived in Paris between 1775 and 1776, 1 year before L'Enfant left the French capital city. Although it is not possible to prove that L'Enfant saw Domingo de Aguirre's map, there is evidence suggesting that he may have. Additionally, despite a lack of documentary proof, one may ask whether Jefferson, during his stay as ambassador to Paris from 1784 to 1789 , may have seen the royal collection of maps and plans, which included that of Aranjuez. This would have been plausible, because the US Constitution (which was drafted in 1787 and went into effect in 1790) anticipated the establishment of a district for the federal capital, and Jefferson, as an architect and a highly cultured man, would have been interested in that information. In the draft that he drew for the new capital, the Capitol and White House appear located in the same relative positions as the Royal Palace and Church of San Antonio in Aranjuez, which is also the way L'Enfant situated them. All of these factors are presented in chronological order in a chronogram (Fig. 2).

The copy of the plans for Aranjuez that was sent to London is conserved at the British Library (Aguirre 1775a), whereas the set that went to Paris is held at the National Library of France (BNF 2016). As stated previously, they should have arrived in Paris between 1775 and 1776, during which time L'Enfant was a student at the Académie Royale de Peinture et de Sculpture (he left the following year for America). He most likely would have been able to see the plan because, among other reasons, it was engraved by the Carmona brothers, Manuel Salvador (1730-1807) and Juan Antonio (1740-1805). Manuel Salvador, the best Spanish engraver at the time, trained in Paris with famous engravers such as Nicolás Gabriel Dupuis. In 1759, he began as an assistant at the Académie Royale de Peinture et de Sculpture, and 2 years later he was named academic and engraver for the King of France. In 1762, he returned to Madrid, and in 1764, he was named academic in painting and engraving. In 1783, he was designated engraver for the royal chamber of the King of Spain (Carrete Parrondo 1989; Gallego 1999).

Between 1759 and 1772, Carmona's years at the Académie Royale de Peinture et de Sculpture in Paris as an assistant and later as an academic coincided with those of the painter Pierre L'Enfant (1704-1787), the father of Pierre Charles L'Enfant. 


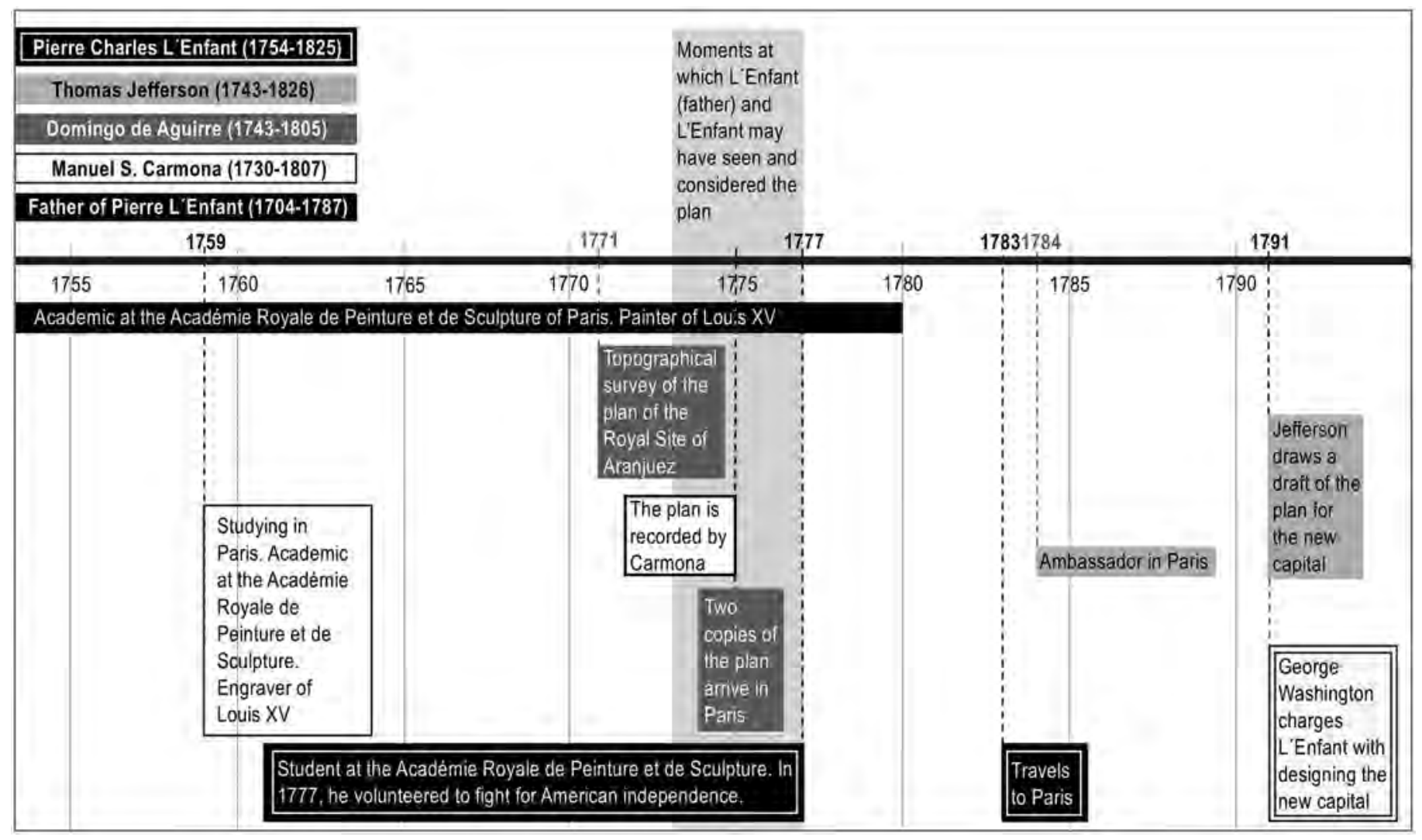

Fig. 2. Chronology of plan for Aranjuez and possible relationship with plans of L'Enfant and Jefferson.

In fact, Pierre L'Enfant, Sr., a student of Charles Parrocel, was admitted to the Académie Royale de Peinture et de Sculpture in 1745, at which he exhibited his works from 1741 to 1771 . He painted landscapes and battle scenes for Louis XV (Warvelle Harbaugh 2013). Carmona and L'Enfant, Sr. were at the Académie together for 12 years, one working as an engraver and the other as a painter; hence, it is safe to assume that they met. When the plans for Aranjuez arrived in Paris, we may assume that they were shown at the Académie Royale de Peinture et de Sculpture, not only because they were for the royal residence of a king of the same French dynasty but also because of their quality and large format, having been magnificently engraved by an old academic from that institution. If this hypothesis is correct, then the plan would have been viewed not only by L'Enfant, Sr. but also by his son, Pierre Charles L'Enfant, who was a student at the Académie Royale at the time.

L'Enfant also traveled to Paris in 1783, after designing the badge and diploma of the Society of the Cincinnati. At that time, the intention to create a new capital was already known, although evidently L'Enfant had not yet been charged with designing it, and although no documentary record exists, he may have seen the large-format plan for Aranjuez again during this trip.

In 1791, George Washington announced the location for the national capital and placed L'Enfant in charge of its design. As stated previously, in March of that year, Jefferson drew a sketch for the new capital in which, atop a grid of streets, he situated the residence of the president and the Capitol in an arrangement similar to that which L'Enfant would use. At L'Enfant's request, Jefferson provided him with maps of various European cities, although L'Enfant indicated that he did not wish to imitate them and would only draw on them to perfect and strengthen his judgement as he sought to prepare an entirely original plan (Helfrich 2016). The maps were of Frankfurt, Karlsruhe, Paris, Orleans, Milan, and Amsterdam (Reps 1992). To these, Khuu (2016) added Versailles, London, New York, Philadelphia, Savannah, Annapolis, and Williamsburg. Aranjuez was not among the maps, although, as we indicated, it had circulated in various European courts. A copy is also held at the Library of Congress (Aguirre 1775c), although its provenance is not known; all we know with certainty is the date on which the map (which is in atlas format) was received by the Geography and Map Division, December 13, 1907.

When did the plan for Aranjuez reach the United States? Diplomatic relations with Spain began in 1777 (Gómez del Campillo 1944) under the envoys Arthur Lee and Benjamin Franklin; John Jay became minister plenipotentiary in 1779; William Carmichael was chargé d'affaires from 1783 to 1794; and William Short was minister resident from 1794 to 1795 (US Embassy and Consulates in Spain 2018). Four letters sent by William Short to Jefferson from Aranjuez between 1793 and 1794 have been preserved, and although their content is not related to the issue that concerns us here, they show that at that point and in the context of bilateral relations between Spain and the United States, the Royal Site of Aranjuez was known among North American politicians (Short 1793a, b, 1794). France and Spain signed the Treaty of Aranjuez on April 12, 1779, establishing that Spain would intervene in favor of the United States in its war for independence (Clarfield 1992).

Was the plan for Aranjuez also sent to the United States, as it was to European capitals? It is not possible to answer this question, although we do know that two copies of L'Enfant's plan for Washington, DC were sent to Madrid. In a letter dated March 26, 1792, the ambassadors of Spain in the United States conveyed Jefferson's offer of land to allow Spain to build its embassy and 
stated that once the plan of Washington, DC was recorded, copies would be sent to Madrid (Archivo Histórico Nacional, Legajo 3894. Estado) (Fernández 2003). The two copies did not arrive in Madrid until November 26, 1796, when Ambassador Jaúdenes returned to Spain (Archivo Histórico Nacional, Legajo 3896. Estado) (Fernández 2003). One of the plans has been preserved in perfect condition in the National Historical Archive in Madrid. It is a copy of the Ellicott Plan of 1792 and remains in the section labelled Estado, MPD, 58 (Guardia 1996).

\section{Forma Urbis of Washington, DC in L'Enfant's Plan: Overview}

The decision to locate the national capital on the Potomac River was a political compromise that was reached in 1790 (Knox 1987). Thomas Jefferson played an important role in the project for the new capital; Fig. 3 shows his sketch for the city of Washington. He was involved in supervising the topographical surveys of the territory, designing the city, and acquiring land ceded to the government by the states of Virginia and Maryland. Jefferson believed that the surface area should consist of 100 square miles and that three individuals should be responsible for the project, including surveyor Andrew Ellicott (1754-1820), who would oversee the surveying of the federal territory, and Pierre Charles L'Enfant (1745-1825), who would collaborate with Ellicott in the placement and design of the buildings. There were two resulting maps: a general plan for the District of Columbia at a scale of 1:31,680 finalized in 1793, which included the main outlines of the urban framework, and another, more detailed map of the city itself at a scale of $1: 19,800$, with the blocks incorporated.

L'Enfant considered some of Jefferson's suggestions for the design for the capital, including his suggestion that the streets should be perpendicular, straight and broad, no less than 100 feet wide, and with 15-foot sidewalks. The heights of the buildings should be balanced, as in Paris. Jefferson drew a sketch consisting of a grid 3 blocks wide and 11 blocks long, with 3 blocks for the president's house and gardens and, to the east, an area of equal size for the Capitol. He connected the two areas with a public walkway that was a precursor to the National Mall (Reps 1992).
L'Enfant reacted unfavorably to the plan by Jefferson, as indicated in his report to President Washington, which stated that a regular complex of houses arranged along plazas and parallel uniform streets was not necessary and that, in his opinion, such a plan would only be possible on a plain in which there were no other interesting element, for which the direction of the streets would not matter (Reps 1992).

Jefferson read this report, and although he expressed differences with L'Enfant's opinions, he continued planning the new capital, preserving his idea of integrating the orthogonal grid with diagonal streets according to the Baroque perspective. The plan for Washington, DC

is most directly derived from the seventeenth-century baroque landscape architecture of the seat of the court of France, and the rise of urbanism in the eighteenth century. L'Enfant, whose father was a painter at the court of Louis XIV, spent his youth at Versailles, where he would have seen the perspectives depicted in his father's views, as well as the physical manifestation of the visual device in the imposing landscape at Versailles. (National Register of Historic Places 2016)

L'Enfant drafted the plan for the new capital in pen in 1791 (Knox 1987). The original plan, barely legible, is preserved in the Library of Congress in Washington, which for the bicentennial of the plan published a copy of the same size and a digital reproduction. In marginal notes, L'Enfant explained how he developed the plan.

He first chose the best locations for important buildings and squares and then connected them via avenues, which enabled them to be reciprocally viewed. Finally, he overlaid this network with a grid of streets oriented in the cardinal directions. The streets converged with the avenues at open-space nodes whose size was determined by the number of intersecting streets. The plan terminates at the base of the escarpment, which was then called Boundary Street and is now Florida Avenue. (Bednar 2006)

The important buildings were the White House and the Capitol, which form two monumental axes in an $\mathrm{L}$ shape at right angles with

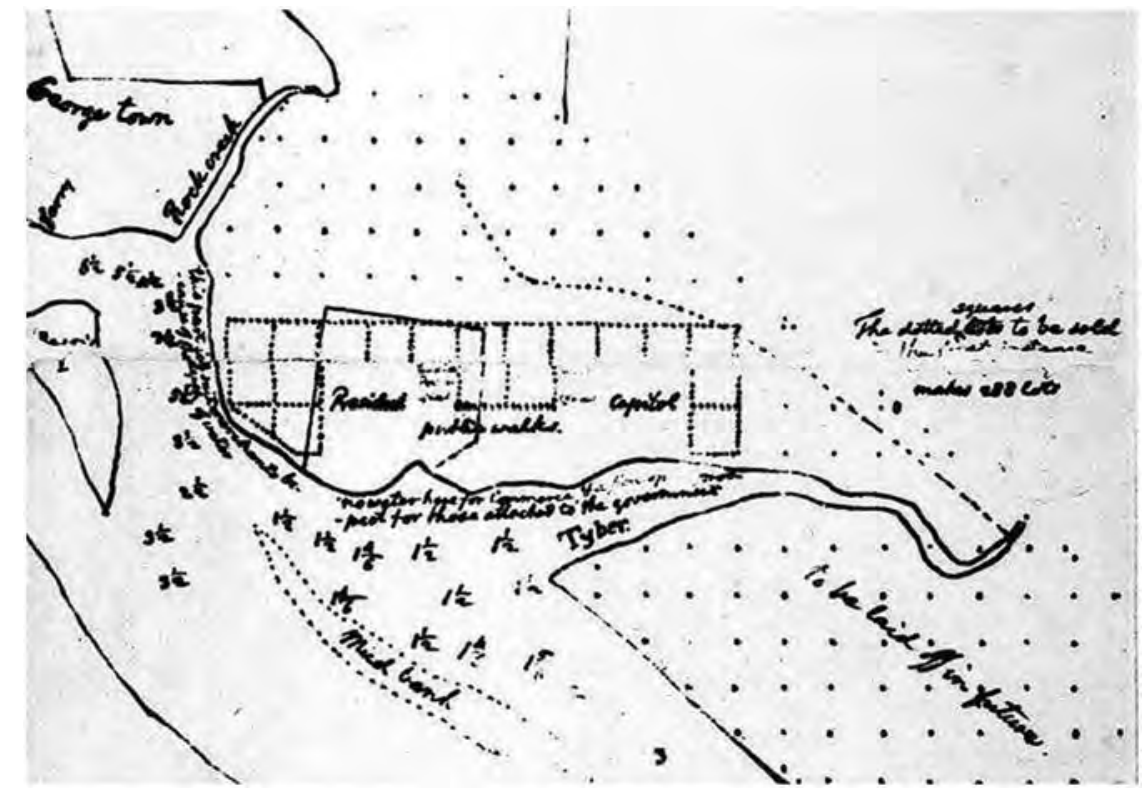

Fig. 3. Plan of the Federal District. (Reprinted from Jefferson 1791.) 
the Potomac River (Fig. 6). At these points converge numerous radial avenues that cross the grid at intriguing angles. However, throughout the axis between the Capitol and the Potomac, "many of the effects of perspective are restricted to paper, becoming lost in incommensurate environments that nonetheless provide L'Enfant's plan with a notable margin or duration; in fact, the road network outlined in 1791 would satisfy the demands of the federal capital for more than a century" (Benevolo 1974).

\section{Forma Urbis of Royal Site of Aranjuez in Domingo De Aguirre's Map: Overview}

The Royal Site of Aranjuez, located 49 km south of Madrid, was a place of leisure for Spanish kings since Felipe II. The architect Bautista de Toledo, a trusted confidant of Miguel Ángel during the project for the Basilica of San Pedro (Witcombe 2004) and the first architect of El Escorial, designed a system of tree-lined avenues there in 1560 based on the geometric shapes of circles, triangles, and squares. These royal possessions consisted of gardens, forests, and orchards with agricultural buildings (Sancho 1995) as well as a palace, still unfinished, unequipped for the needs of the kings of the new Bourbon dynasty: Felipe V, Fernando VI, and Carlos III. Meanwhile, lodging alongside the royal family was required for the court and foreign ambassadors and troops, for which a town attached to the Royal Palace was designed by Giacomo Bonavía in 1750 under Fernando VI. This complex is a symbiosis of the orthogonal grid and the Baroque trident of diagonal streets that break with the rigid scheme and make possible grand vistas in the style of Versailles. The significance of the Royal Site of
Aranjuez is such that UNESCO declared it a World Heritage Site (UNESCO 2001). It was described as follows:

The Aranjuez cultural landscape is an entity of complex relationships: between nature and humanity, between sinuous watercourses and geometric landscape design, between the rural and the urban, between the carefully regulated treescapes and the architecture of palatial buildings. 300 years of royal attention to the development and care of this landscape have seen it express an evolution of concepts from humanism and political centralization, to values such as those found in its eighteenth-century French-style Baroque garden, to the urban living modes which were established side by side with the sciences of plant acclimatization and stock-breeding during the Age of Enlightenment.

Bonavía's project is captured in the plan entitled La Topografía del Real Sitio de Aranjuez (The Topography of the Royal Site of Aranjuez) (Fig. 4) by the military engineer Domingo de Aguirre. The 16 sheets (Fig. 4) have total dimensions of $325 \times 340 \mathrm{~cm}$. The map used in this study, Sheet 10, is highlighted with a box in Fig. 4. It describes the city as a "symbolic image of a geographic reality" (Dorling and Fairbairn 1997), interpreting the intention by King Charles III to graphically establish the image of the Royal Site as a model of the integration of the ideal form of rationalized agriculture into the urban form. The plan offers the monarch "a symbolic instrument that represents his power" (Harley 1988). Domingo de Aguirre conducted rigorous fieldwork with the measurements and astronomical observations needed for a topographic survey (San-Antonio-Gómez 2015). The original map was finished in June 1773 and recorded after the king's approval. It consists of
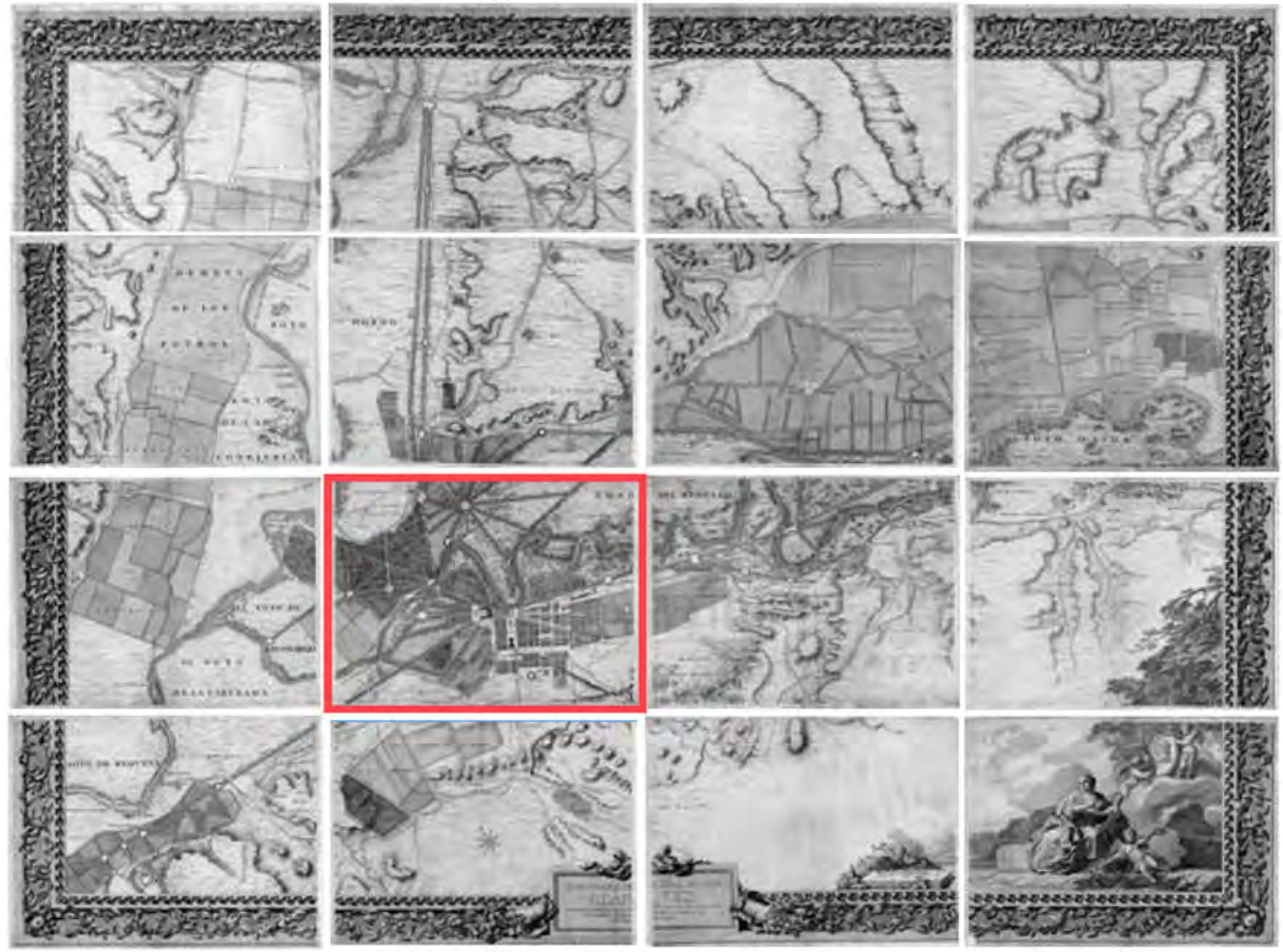

Fig. 4. Topographic surveying of the Royal Site of Aranjuez, Sheets 1-16. (Reprinted with permission from Aguirre 1775b, Spain, Ministry of Defense, Geographical Center of the Army.) 


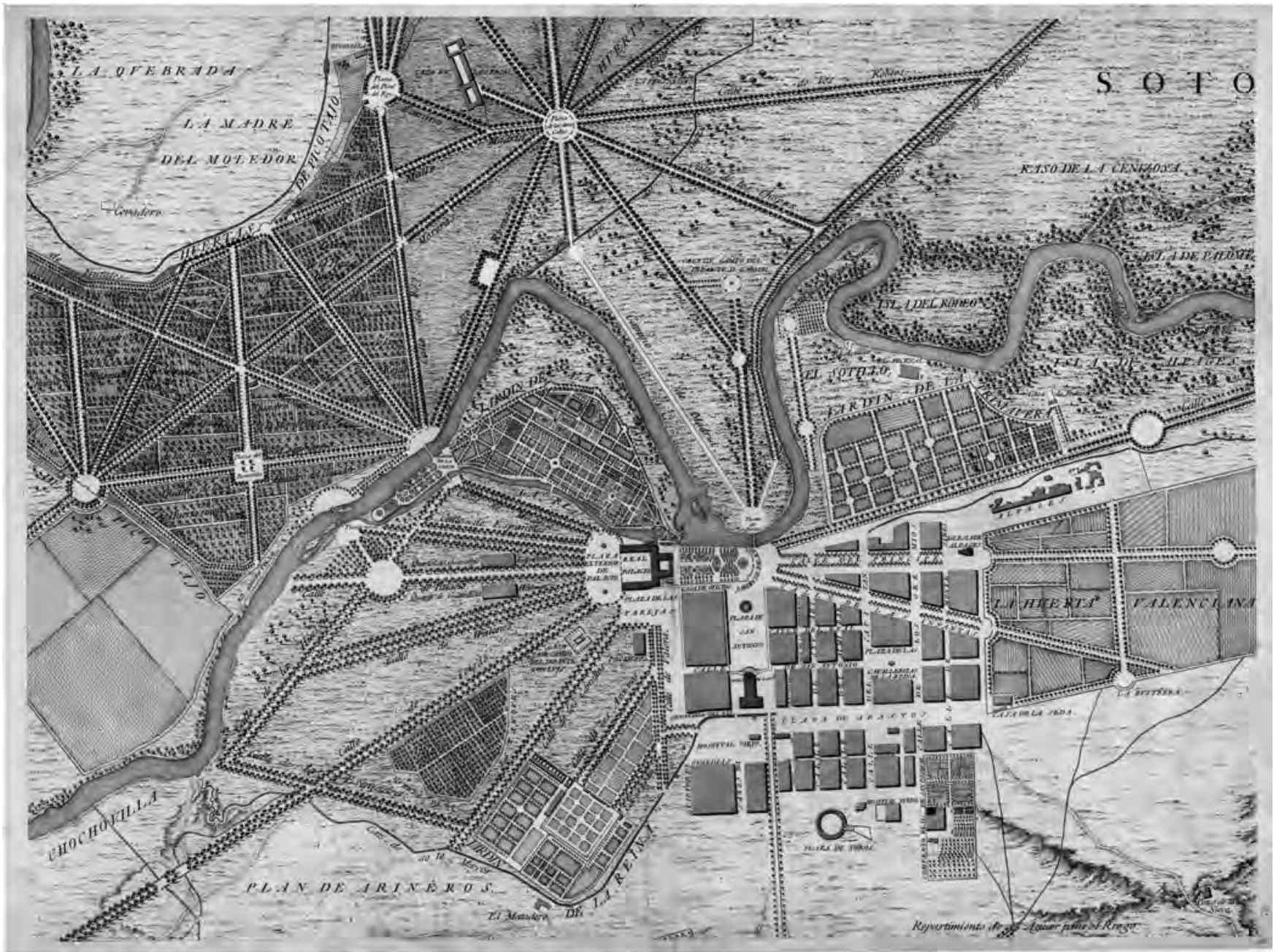

Fig. 5. Topographic surveying of the Royal Site of Aranjuez, Sheet 10. (Reprinted with permission from Aguirre 1775b, Spain, Ministry of Defense, Geographical Center of the Army.)

16 pages measuring $64 \times 84 \mathrm{~cm}$. This paper reproduces only Sheet 10 (Fig. 5). The etching plates with which it was created are kept at the Calcografía Nacional. The unit of measure was the Spanish vara. Its scale, based on the graphic scale of 800 varas $=$ $160.1 \mathrm{~mm}$, is $1: 4,166.48$, considering that 1 vara $=835.9 \mathrm{~mm}$ (San-Antonio-Gómez et al. 2015).

Aranjuez combines two styles of urban planning from two different centuries: the Renaissance approach by Juan Bautista de Toledo and the Baroque approach by Bonavía (San-AntonioGómez et al. 2014). Bonavía integrated the orthogonal grid of the early Spanish cities in the Americas and the Baroque tradition of the trident (il Tridente) superimposed onto it, as at Versailles. The grid at Versailles has much larger dimensions than that at Aranjuez; the central axis of the trident at Versailles has a length of nearly $5 \mathrm{~km}$, whereas at Aranjuez it measures approximately $3 \mathrm{~km}$.

\section{Plans of L'Enfant and Domingo De Aguirre: Evidence and Common Link}

The originality of Bonavía's plan for the Royal Site of Aranjuez lies in its scenic conception of the urban landscape, which generates a complex of great visual value, such as that comprising the Parterre Garden and Plaza de San Antonio. These are two rectangular spaces arranged in an L shape at the extremes of which are situated the Royal Palace and the Church of San Antonio. The link between these two contiguous orthogonal spaces is not visual-they are not divided-but rather compositional, following the scheme of two rectangles before which are Greek or Roman columns such as at Miletus or Villa Adriana. They even recall—although on a much larger scale-L-shaped Italian plazas such as the Signoría in Florence and the San Marcos in Venice. Meanwhile, the tangency of the Tajo River along the long edge of the rectangle of Parterre Garden offers another landscape nuance to the complex (Figs. 1 and 6).

The same arrangement of the two rectangular spaces in an $\mathrm{L}$ shape at the ends of which are situated iconic buildings was adopted by L'Enfant for Washington, DC in 1791, some 40 years after Bonavía's plan for Aranjuez. L'Enfant located at the ends of two large rectangular and orthogonal urban spaces the city's two most representative buildings: the Capitol and the White House (Fig. 6). However, because there are three branches of government (legislative, executive, and judicial), why did L'Enfant fail to reserve a similarly prominent space for the Supreme Court? It was given the site where City Hall was later built. Although an important building appears there in L'Enfant's plan, there is no direct reference to it in the legend, and only one mention appears in his reports. The site was halfway between the Capitol and the home of the president and had a secondary role in the structure of the plan (Helfrich 2016). 


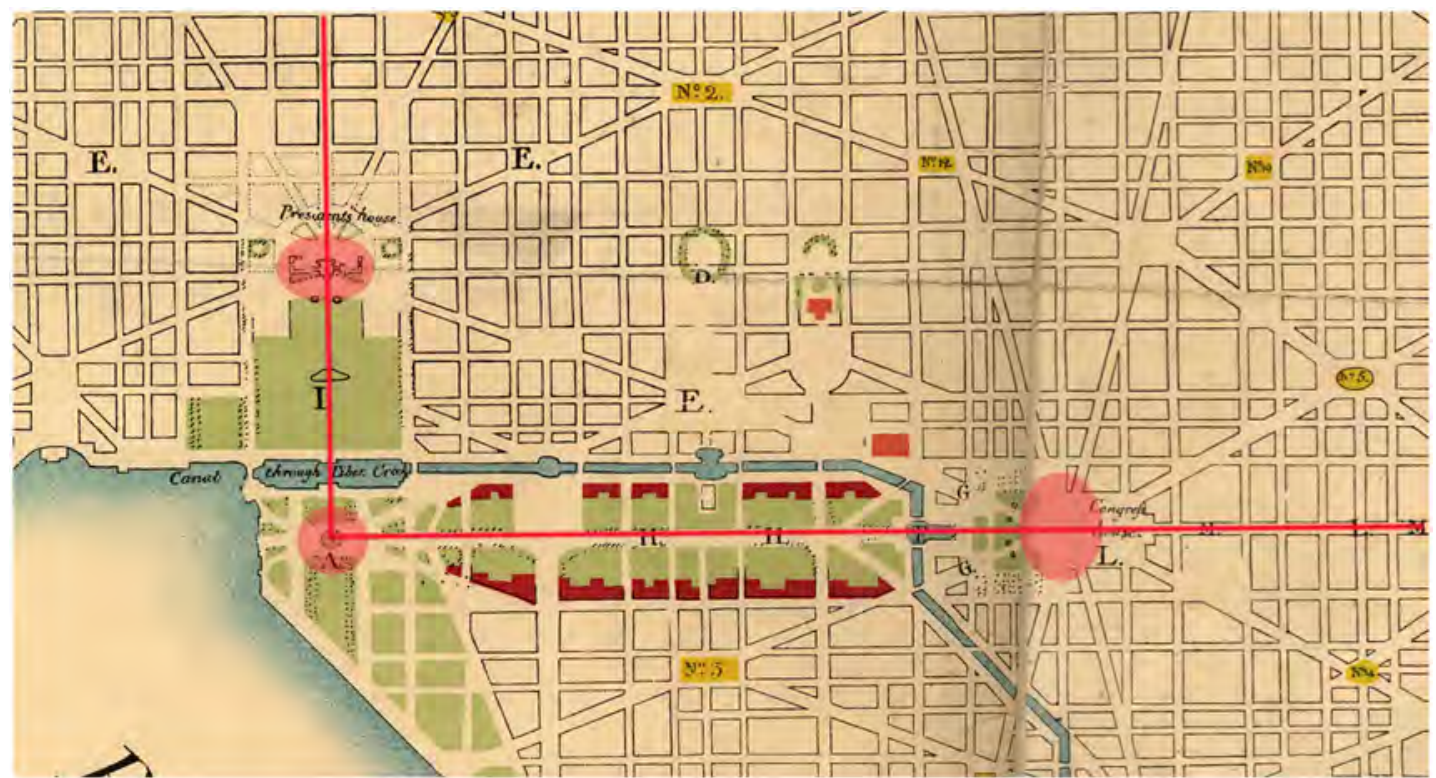

(a)

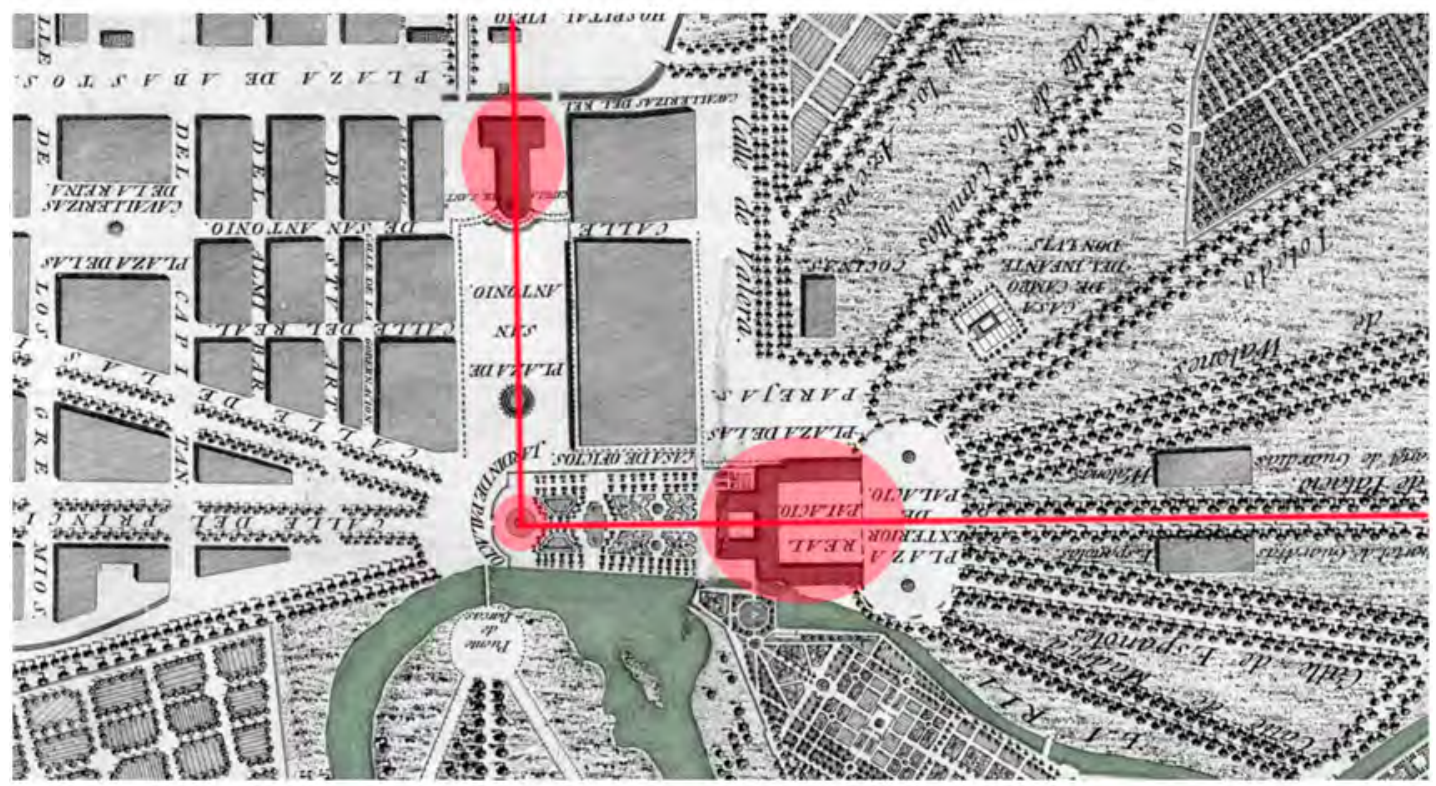

(b)

Fig. 6. Similarities in disposition of main points (L shape): (a) plan of L'Enfant for Washington, DC (adapted from L'Enfant 1791); and (b) Royal Site of Aranjuez (adapted with permission from Aguirre 1775b, Spain, Ministry of Defense, Geographical Center of the Army).

An answer to this question may be found in the analogy between Washington, DC and Aranjuez, where there are only two main buildings to compare in terms of their locations. In effect, in Washington, DC, the Capitol occupies the site where the Royal Palace appears in Aranjuez, and the White House occupies that of the Church of San Antonio; hence, the National Mall is equivalent to the Parterre Garden, and the Ellipse in front of the White House is equivalent to the Plaza de San Antonio (Fig. 6). The place in Washington, DC that is analogous to the Royal Palace (the home of the king) is not the president's house, but rather the seat of Congress (which represents the people), which is logical considering that the new nation was a republic and not a monarchy, in which the general feeling was reflected in words such as these by Jefferson: "I was much an enemy to monarchy before I came to Europe. I am ten thousand times more so since I have seen what they are" (Jefferson 1788).

L'Enfant's plan is today disfigured by the McMillan Plan of 1902, which extended the National Mall down to the Lincoln Memorial on reclaimed land by the Potomac such that the original L became a T. When McMillan announced his plan for the avenue, he made it clear that he saw it as being consistent with L'Enfant's dream and as an opportunity to group public buildings together (Peterson 2007).

Another surprisingly similar element in L'Enfant's plan is the tangency of the Potomac River along the short edge of the Mall, whereas at Aranjuez, the Tajo River runs along the long edge of Parterre Garden. There is also the existence of the two canals: that of the Potomac, which runs from the north and east side of the Mall, 


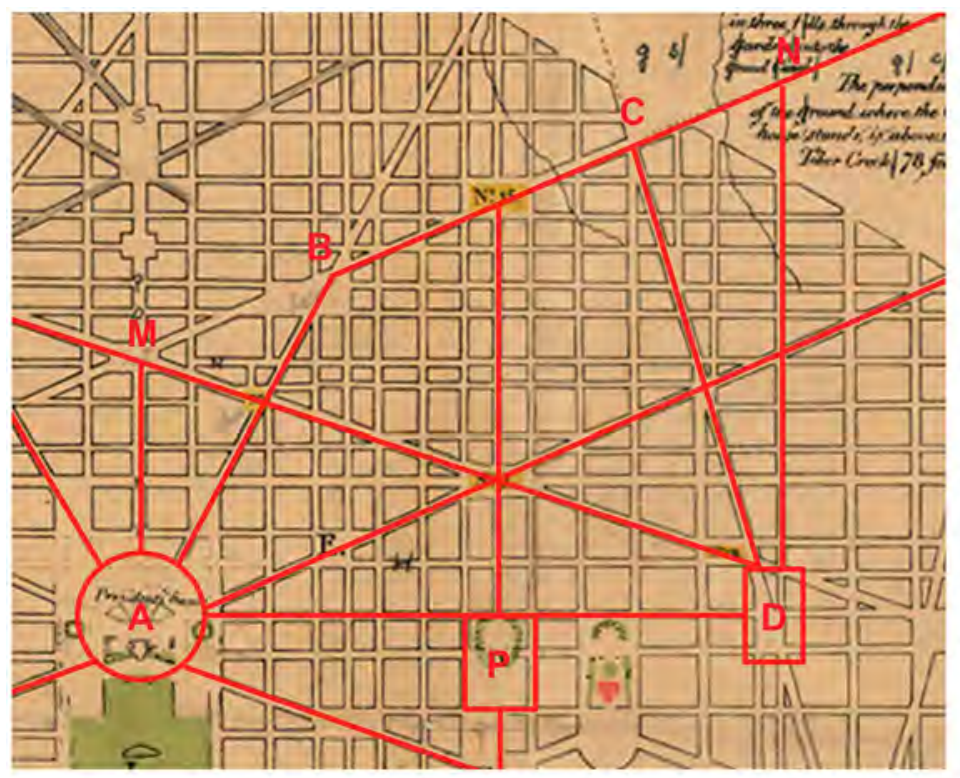

(a)

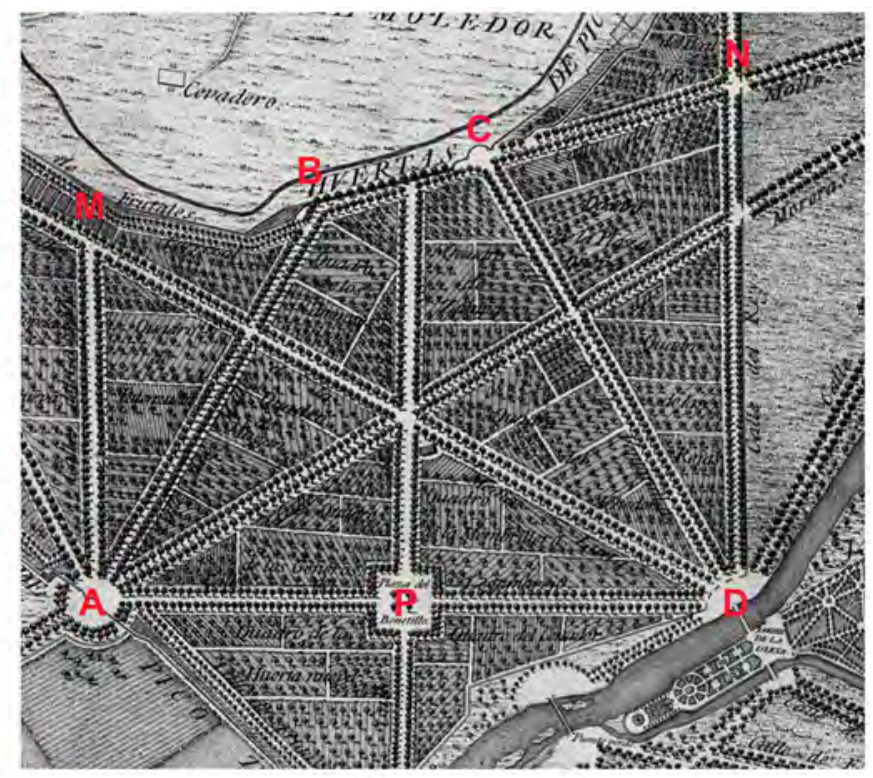

(b)

Fig. 7. Similarities between avenues and focal points of plans: (a) plan of L'Enfant for Washington, DC (adapted from L'Enfant 1791); (b) Royal Site of Aranjuez (adapted with permission from Aguirre 1775b, Spain, Ministry of Defense, Geographical Center of the Army).

flowing at a $45^{\circ}$ angle toward the area south of the Capitol; at Aranjuez, a canal flows from the north side of the Parterre Garden at a $45^{\circ}$ angle toward the north.

The coincidences do not end there. Monuments are located at the intersections of the perpendicular axes that extend from the Capitol and the White House in Washington, DC and from the Royal Palace and Church of San Antonio in Aranjuez. In the national capital, L'Enfant thought of this location for the equestrian statue of George Washington (ordered to be erected in 1783 by the Continental Congress), although ultimately it was not located here. Placed in an analogous position in Aranjuez was the Fountain of Hercules and Antaeus, which remains there today.

Other similarities can be found between some avenues in Washington, DC and those of the orchards at Aranjuez. Both plans have a trapezoid with angles at Points $A$ (the site of the White House), B, C, and D. At Aranjuez, if Sides AB and CD are extended, they form with $\mathrm{AD}$ an equilateral triangle that is scalene in Washington, DC. In both cases, on Side AB, at Point $\mathrm{P}$, is an avenue that is the height of the triangles, but only at Aranjuez are the other two avenues the height of the triangle. In the two plans, there is also a quadrilateral shape formed by avenues whose angles are Points A, M, N, and D. Meanwhile, in both cases, Point $\mathrm{P}$ is located in a rectangular plaza (Fig. 7). In this comparison, the L'Enfant plan is from 1791, whereas the avenues at Aranjuez date back to 1560 (Luengo Añón 2008), as observed in the plan attributed to Juan de Herrera (Fig. 8). The implication is that the design of Aranjuez is not Baroque (as may be interpreted), but rather Renaissance.

There are other similarities in the 12 avenues that depart from the Capitol-although some have suffered transformations - the geometric center of which is the cupola. These 12 avenues have their parallel at Aranjuez in the Plaza de las Doce Calles (Fig. 9).

With their focal point at the Capitol, the avenues have their counterparts at the Royal Palace at Aranjuez, from which the avenues radiate outward. However, the radial scheme of Washington, DC is a simplification of that of Aranjuez. In effect, in L'Enfant's plan, the 12 avenues are structured around two main perpendicular

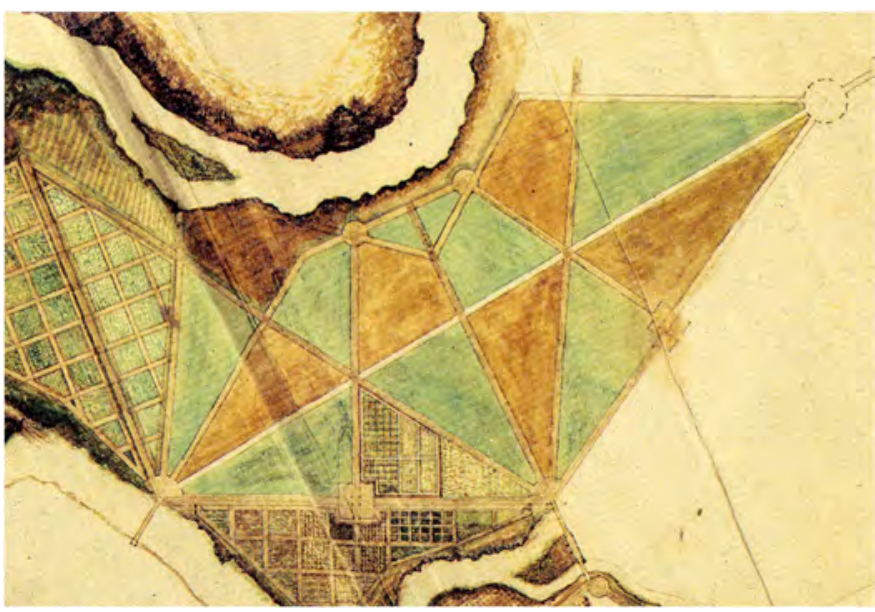

Fig. 8. Highlighted detail from Palacio, Casas de Oficios, calles de Toledo y Madrid y Huertas de Picotajo (1580) of Royal Site of Aranjuez. (Reprinted with permission from Herrera 1580, (C) Patrimonio Nacional.)

axes: the first is composed of East Capitol St. SE, which extends in the original plan with Avenue $\mathrm{H}$ (the longitudinal axis of the Mall); the second is formed by South Capitol St. SE and North Capitol St. NW. The other avenues are Maryland Avenue NE and Maryland Avenue SW, Delaware Avenue NE and Delaware Avenue SW, New Jersey Avenue NW and New Jersey Avenue SE, and Pennsylvania Avenue NW and Pennsylvania Avenue SE.

The focal arrangement around the Royal Palace at Aranjuez is more complex because of the pre-existing Renaissance avenues that Bonvía integrated into his urban space. At the front of the Royal Palace are three foci: that of the main door, from which a trident extends with two confluent avenues, with the central axis composed of the two parallel streets; from the same foci extends a fourth avenue (the road to Toledo), which existed centuries before. 


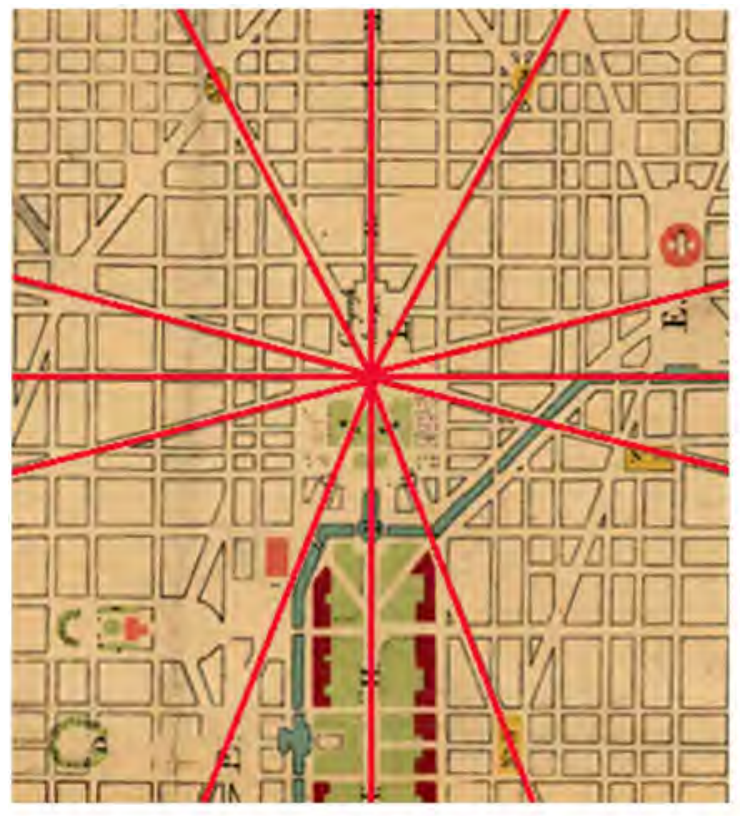

(a)

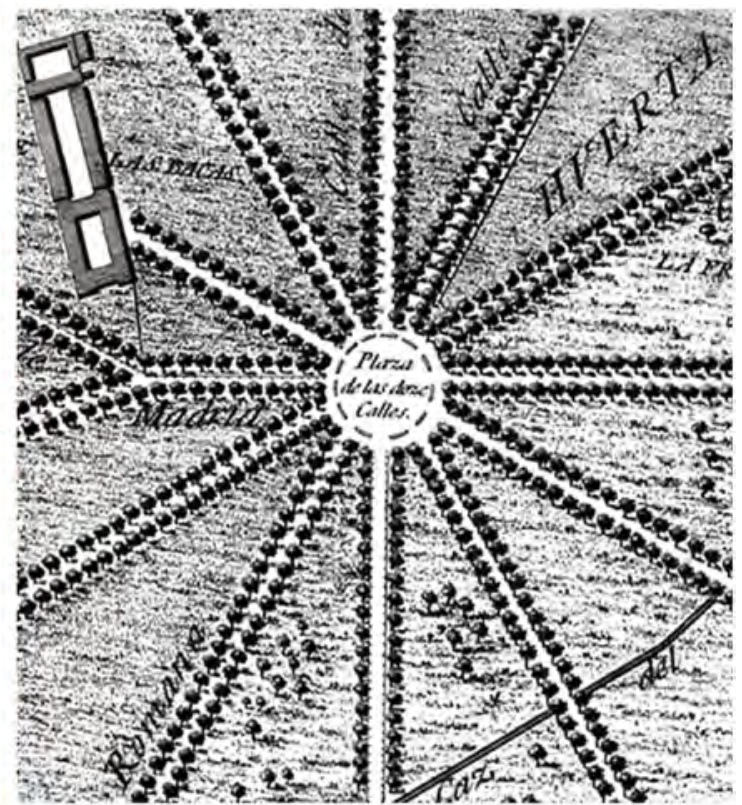

(b)

Fig. 9. Similarities of 12 avenues: (a) plan of L'Enfant for Washington, DC (adapted from L'Enfant 1791); and (b) Royal Site of Aranjuez (reprinted with permission from Aguirre 1775b, Spain, Ministry of Defense, Geographical Center of the Army).

Two avenues (one existing and the other new) extend from both of the other two foci, also in front of the Royal Palace and situated on either side of the previous focal point before broadening with the lateral wings. The new avenue from the focal point at the right is very short and meets another pre-existing avenue, which is that of the axis of the Jardines de la Isla. In this manner, as in Washington, DC, there are nine avenues, although of a different character and arranged less symmetrically than those that extend out from the US Capitol building.

In Washington, DC, the three remaining avenues form a trident comprising Pennsylvania Avenue NW and Maryland Avenue SW and, as an axis, Avenue $\mathrm{H}$ (the longitudinal axis of the Mall in
L'Enfant's original plan). At Aranjuez, a similar trident travels along the orthogonal longitudinal axis in front of the Royal Palace, with its focus situated at the center of the pond at which the Hercules and Antaeus statue is located. Although in Washington, DC there is a single focal point from which streets radiate, at Aranjuez there are two main foci (one of those is multiple) traveling along the longitudinal axis.

The double focal arrangement at Aranjuez is like that of Versailles, which is also true of the grid in Washington, DC. Of the two foci at Versailles, the first and main focus would be the center of the octagonal pond at the end of the Grand Canal, from which seven avenues depart. The second focus at Versailles is

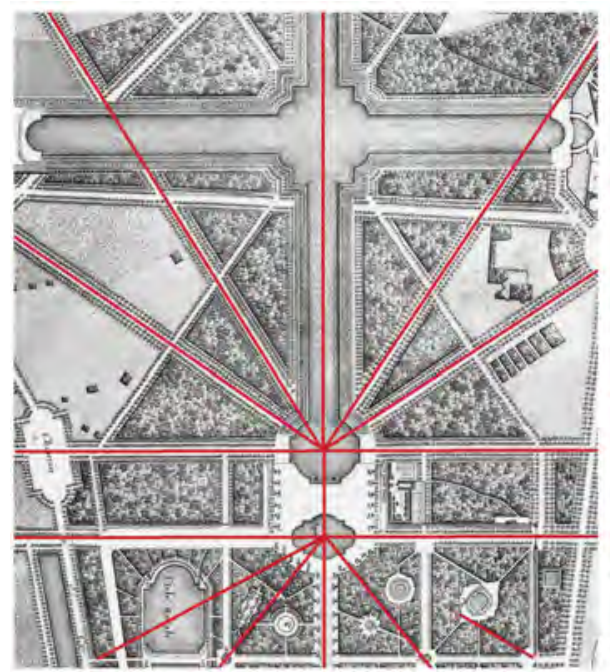

(a)

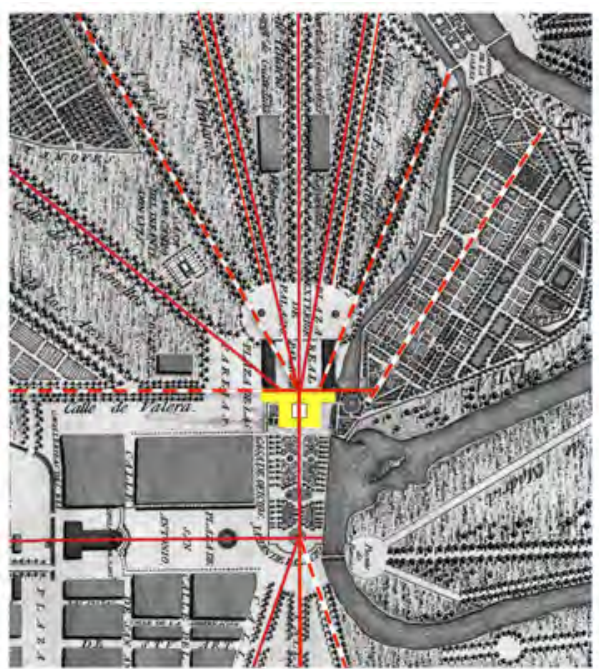

(b)

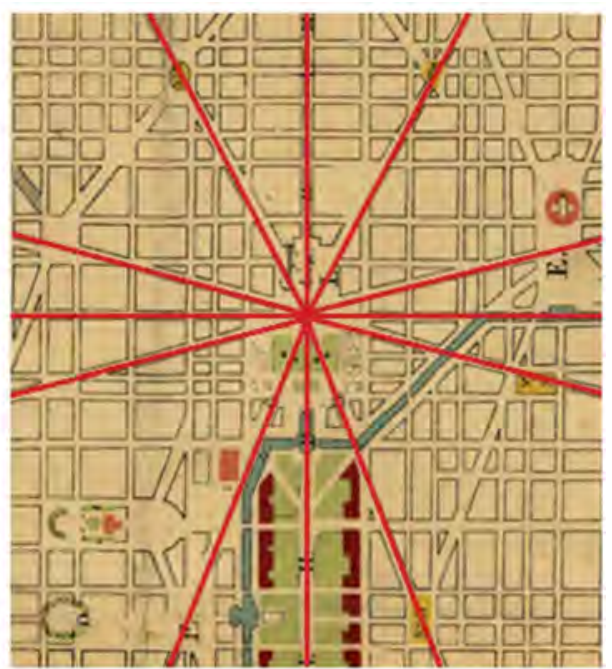

(c)

Fig. 10. Detail of focal systems of avenues: (a) Versailles (adapted from Delagrive 1746); (b) Royal Site of Aranjuez (adapted with permission from Aguirre 1775b, Spain, Ministry of Defense, Geographical Center of the Army); and (c) Plan of L'Enfant for Washington, DC (adapted from L'Enfant 1791). 
located at the center of the pond called the Bassin d'Apollon (situated at the end of the main axis of the Grand Canal), from which a trident extends, and, orthogonally to the main axis, two avenues as well as one shorter avenue, which makes six avenues in total (Fig. 10).

\section{Conclusion}

The formas urbis of the Royal Site of Aranjuez and of Washington, DC share a common Baroque origin in Versailles, the city and its gardens alike, which in turn owes a debt to Rome under Pope Sixtus $\mathrm{V}$ and its Baroque trident (il Tridente), which was so often imitated in European and American cities. The happy marriage of Miletus' grid plan with Baroque diagonals finds its maximum expression on a large scale in the plans for Versailles and Washington, DC-and on a smaller scale at Aranjuez, where the plan for the Renaissance orchards anticipated the grand planning of subsequent years.

There is no documentation demonstrating that L'Enfant drew on the landscape of Versailles or that he was inspired by the plan for the Royal Site of Aranjuez, therefore; it is not possible to prove documentarily that L'Enfant was inspired by the plan of Domingo de Aguirre of the Royal Site of Aranjuez, although as this research shown, he had a chronological and locational occasion to do so, and the similarities are as evident as with Versailles.

Two primary compositions that highlight the similarity between the scenographic diagrams are (1) the two large rectangular spaces arranged in an $\mathrm{L}$ shape at the heads of which are located the most emblematic buildings, i.e., the Capitol and the White House in Washington, DC, and the Royal Palace and the Church of San Antonio in Aranjuez; and (2) that of some grids of streets, such as the 12 radial avenues or those that form trapezoids whose corners form the emblematic sites of the city. This uncovered evidence is a significant contribution that enriches with new approaches, hitherto unknown, the history of urban planning in Washington, DC and, by extension, the urban history of the cities of the United States.

In short, although this case study is very specific for the undoubted similarities between the plan of L'Enfant and that for the Royal Site of Aranjuez, this methodology could be applied, with the logical adaptations, to look for possible similarities, no longer so evident, between the plan for Washington, DC and the plans of the cities that Jefferson offered to L'Enfant and those cited in this work: the European cities of Frankfurt, Karlsruhe, Paris, Orleans, Milan, Amsterdam, London; and the American cities of New York, Philadelphia, Savannah, Annapolis, and Williamsburg.

\section{Acknowledgments}

This work is part of the research project entitled La forma urbis del Real Sitio de Aranjuez en la cartografía histórica: Análisis gráfico, transcripción y restitución planimétrica [The forma urbis of the Royal Site of Aranjuez in cartographic history: Graphic analysis, transcription and planimetric restitution] funded by grants for research projects from the National Plan for Scientific Research, Development and Technological Innovation under Spain's Ministry of Education and Science.

\section{References}

Aguirre, D. 1775a. Topografia del Real Sitio de Aranjuez. London: British Library.

Aguirre, D. 1775b. Topographic surveying of the royal site of Aranjuez. Localisation: Army Geographical Center (Servicio Geográfico del
Ejercito). Map references SG.AR.E-T.8-C.1-116(1-16). Madrid, Spain: Ministry of Defense.

Aguirre, D. 1775c. Topografia del real sitio de aranjuez. Washington, DC: Library of Congress.

Aranjuez. 2017. "Aerial view of the compounds of the Royal Palace and Plaza de San Antonio de Aranjuez." Accessed October 9, 2017. http:// www.jdiezarnal.com/palaciodearanjuezvista01.jpg.

Bednar, M. J. 2006. L' Enfant's legacy: public open spaces in Washington, $D C$. Baltimore: Johns Hopkins University Press.

Benevolo, L. 1974. Historia de la Arquitectura Moderna. Barcelona, Spain: Gustavo Gili.

Berg, S. W. 2008. Grand avenues. New York: Vintage Books, Random House.

BNF (Bibliothèque Nationale de France). 2016. Topografía del Real Sitio de Aranjuez. Registre C. 2690 = Ge CC 759.-Pf II = GE 760. Type: document cartographique, monographie. Localisation: RichelieuCartes et plans- magasin.

Carrete Parrondo, J. 1989. El grabado a buril en la España Ilustrada. Manuel Salvador Carmona. Madrid, Spain: Fábrica Nacional de Moneda y Timbre.

Chen, Y., S. Yoo, and J. Hwang. 2017. "Fuzzy multiple criteria decisionmaking assessment of urban conservation in historic districts: Case study of Wenming Historic Block in Kunming City, China." J. Urban Plann. Dev. 143 (1): 05016008. https://doi.org/10.1061/(ASCE)UP .1943-5444.0000334.

Clarfield, G. 1992. United States diplomatic history: From revolution to empire. Upper Saddle River, NJ: Prentice-Hall.

Delagrive. 1746. Plan de Versailles. Numéro d'inventaire, GE DD-2987 (834 B). Paris: Bibliothèque Nationale de France, Département Cartes et plans.

Dorling, D., and D. Fairbairn. 1997. Mapping: Ways of representing the world. Harlow, Essex, UK: Longman.

Fernández, X. 2003. El arquitecto norteamericano Thomas Jefferson (1743-1826) y su relación con España. La Coruña, Spain: Universidad de la Coruña.

Gallego, A. 1999. Historia del grabado en España. Madrid, Spain: Cátedra.

Gómez del Campillo, M. 1944. Relaciones diplomáticas entre España y Estados Unidos según los documentos del Archivo Histórico Nacional, 2 volúmenes. Madrid, Spain: CSIC.

Guardia, C. 1996. "La ciudad federal y la ilustración española." Revista de Estudios Norteamericanos 4: 304-305.

Harley, J. B. 1988. "Maps, knowledge and power." In The iconography of landscape, edited by D. Cosgrove, and S. Daniels, 277-312. Cambridge, UK: Cambridge University Press.

Helfrich, K. G. F. 2016. "Designing the Nation's Capital: The 1901 Plan for Washington, DC: ‘Beloved Ancien': William T. Partridge's recollections of the Senate park commission and the subsequent mall development." Accessed July 8, 2016. https://www.nps.gov/parkhistory /online_books/ncr/designing-capital/sec7.html.

Herrera, J. 1580. Plano del Palacio, Casas de Oficios, calles de Toledo y Madrid y Huertas de Picotajo. Madrid, Spain: Library of the Royal Palace of Madrid.

Jefferson, T. 1788. "From Thomas Jefferson to George Washington, 2 May 1788." Founders Online, National Archives. [Original source: The Papers of Thomas Jefferson, vol. 13, March-7 October 1788, ed. Julian P. Boyd. Princeton: Princeton University Press, 1956, pp. 124-129]. Accessed July 12, 2016. http://founders.archives.gov/documents /Jefferson/01-13-02-0059.

Jefferson, T. 1791. "Plan of the Federal District. Manuscript map." Manuscript Division (102) (Library of Congress). Accessed December 15, 2017. http://www.loc.gov/exhibits/jefferson/images/vc102.jpg.

Khuu, D., 2016. "1751-1799. Founding of the Federal City and L'Enfant's Plan.” Accessed July 8, 2016. http://threegp.wixsite.com/washingtondc /founding-lenfant-plan.

Knox, P. L. 1987. "The Washington metropolitan area." Cities 4 (4): 290-298. https://doi.org/10.1016/0264-2751(87)90090-4.

L'Enfant, P. C. 1791. "Plan of the city intended for the permanent seat of the government of the] United States : projected agreeable to the direction of the President of the United States, in pursuance of an act of Congress 
passed the sixteenth day of July, MDCCXC, "establishing the permanent seat on the bank of Potowmac"." [Washington D.C.] [Washington: United States Coast and Geodetic Survey] [Map] Retrieved from the Library of Congress. Accessed December 4, 2018. https://www.loc .gov/item/88694196/.

Li, M., J. Xu, and X. Zhang. 2017. "Spatial-sensitivity analysis for urban color planning: Study of Luoyang City, China." J. Urban Plann. Dev. 143 (1): 05016014. https://doi.org/10.1061/(ASCE)UP.1943-5444 0000345

Luengo Añón, A. 2008. Aranjuez. La construcción de un paisaje. Utopía y realidad. Madrid, Spain: Instituto de Estudios Madrileños, CSIC, Doce Calles.

National Register of Historic Places. 2016. "National Park Service, at the entrance dedicated." L'Enfant Plan of the City of Washington, District of Columbia." pp. 35-36. Accessed December 4, 2018. http://focus.nps .gov/pdfhost/docs/NRHP/Text/97000332.pdf.

Peterson, J. A. 2007. “The nation's first comprehensive city plan a political analysis of the McMillan Plan for Washington, DC, 19001902." J. Am. Plann. Assoc. 51 (2): 134-150. https://doi.org/10.1080 /01944368508976205.

Pipa, H., J. de Brito, and C. O. Cruz. 2017. "Sustainable rehabilitation of historical urban areas: Portuguese case of the urban rehabilitation societies." J. Urban Plann. Dev. 143 (1): 05016011. https://doi.org/10 .1061/(ASCE)UP.1943-5444.0000348.

Reps, J. 1992. The making of urban America: a history of city planning in the United States. Princeton, NJ: Princeton University Press.

San-Antonio-Gómez, C., C. Velilla, and F. Manzano-Agugliaro. 2014. "Urban and landscape changes through historical maps: The Real Sitio of Aranjuez (1775-2005), a case study." Comput. Environ. Urban Syst 44: 47-58. https://doi.org/10.1016/j.compenvurbsys.2013.12.001.
San-Antonio-Gómez, C., C. Velilla, and F. Manzano-Agugliaro. 2015. "Photogrammetric techniques and surveying applied to historical map analysis." Survey Rev. 47 (341): 115-128. https://doi.org/10 $.1179 / 1752270614$ Y.0000000098.

Sancho, J. L. 1991. "Doce planos de Aranjuez: Domingo de Aguirre." In Cartografía histórica de Aranjuez. Cinco siglos de ordenación del territorio, edited by J. L. Sancho, and R. J. Martínez-Atienza, 37. Aranjuez, Spain: Doce Calles.

Sancho, J. L. 1995. La Arquitectura de los Sitios Reales. Catálogo histórico de los palacios, jardines y patronatos reales del Patrimonio Nacional. Madrid, Spain: Patrimonio Nacional.

Short, W. 1793a. "William Short to Thomas Jefferson, 2 April 1793. Library of Congress." Accessed December 4, 2018. https://www.loc .gov/resource/mtj1.017_1200_1201/?sp=1.

Short, W. 1793b. "William Short to Thomas Jefferson, 5 April 1793. Library of Congress." Accessed December 4, 2018. https://www.loc .gov/resource/mtj1.017_1220_1235/?sp=1.

Short, W. 1794. "William Short to Thomas Jefferson, 22 May 1794. Library of Congress." Accessed December 4, 2018. https://www.loc.gov /resource/mtj1.020_0110_0115/?sp=1.

UNESCO. 2001. "World heritage committee inscribes 31 new sites on the world heritage list." Accessed December 4, 2018. http://whc.unesco.org /en/news/143.

US Embassy and Consulates in Spain. 2018. "Former US ambassadors." Accessed December 4, 2018. https://es.usembassy.gov/our-relationship /our-ambassador/former-u-s-ambassadors/.

Warvelle Harbaugh, M. 2013. The first forty years of Washington DC 670, Architecture. Morrisville, NC: Lulu Press.

Witcombe, C. L. C. E. 2004. Copyright in the Renaissance: Prints and the privilegio in sixteenth-century Venice and Rome. Leiden, Netherlands: Brill. 